\title{
Use of muscle MRI in an atypical presentation of FSHD2
}

\author{
Aaron Jesuthasan, ${ }^{1}$ Sachit Shah, ${ }^{2}$ Jasper M Morrow ${ }^{3}$
}

'University College Hospital, University College London Hospitals NHS Foundation Trust, London, UK

${ }^{2}$ Lysholm Department of Neuroradiology, National Hospital for Neurology and Neurosurgery, London, UK ${ }^{3}$ Department of Neuromuscular Diseases, Queen Square UCL Institute of Neurology, London, UK

\section{Correspondence to} Dr Jasper M Morrow; j.morrow@ucl.ac.uk

Accepted 24 May 2020

\section{DESCRIPTION}

A 35-year-old right-handed man was referred with gradually progressive bilateral shoulder weakness, first noticed at age 16 when he was unable to fully lift his arms above his head. On examination, he had bilateral severe wasting of trapezius muscles, associated marked scapular winging and some thinning of the pectoral muscles. There were neither symptoms nor signs of facial or lower limb weakness. He additionally had no relevant family history. Creatine kinase (CK) was 217 IU/L (38-204). Facioscapulohumeral muscular dystrophy (FSHD) 1 genetic testing was negative, hence further investigations were performed. Electromyography (EMG) showed complete absence of activity in the trapezius bilaterally, but was normal in the rest of the shoulder, upper limb and bulbar muscles, including the sternomastoid. This raised the possibility of congenital bilateral aplasia of the trapezius. However, muscle MRI (figure 1) showed additional involvement in the serratus anterior, teres major and adductor longus muscles. Further genetic testing confirmed

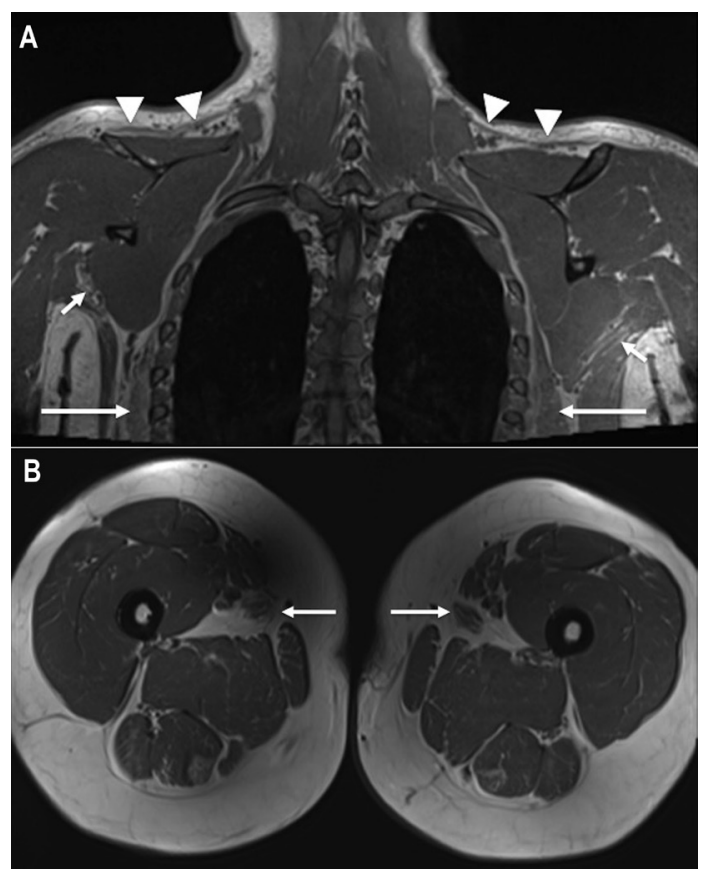

Figure 1 (A) Coronal T1-weighted MRI of the neck, shoulder girdle and upper thorax, demonstrating severe atrophy of trapezius on both sides (arrowheads), as well as less marked atrophy and fatty change involving serratus anterior (long arrows) and teres major (short arrows) bilaterally. (B) Axial T1-weighted MRI of both thighs, demonstrating selective atrophy and fatty change affecting adductor longus on both sides (arrows).

\section{Learning points}

- Symmetrical muscle involvement does not rule out the possibility of facioscapulohumeral muscular dystrophy (FSHD).

- Muscle MRI is a useful modality to validate and accurately detect muscle involvement in suspected FSHD cases.

- FSHD1 and FSHD2 are indistinguishable cases clinically and on muscle MRI, but FSHD2 is more commonly sporadic due to digenic inheritance.

hypomethylation in chromosome 4q35 (21\%, normal $>45 \%$ ) and an SMCHD1 gene mutation (c.[2879_2833 de], p.[Ile960Serfs*10]), affirming a diagnosis of FSHD2.

FSHD occurs as a result of reduced methylation in the D4Z4 tandem repeat region at $4 \mathrm{q} 35$ either due to a reduced number of repeats (FSHD1) or a mutation in the methylation gene SMCHD1 (FSHD2). ${ }^{1}$ The clinical features of FSHD2 are indistinguishable from FSHD1, characterised by facial muscle weakness in the vast majority, usually asymmetric weakness of scapular fixator muscles and most patients often also display weakness in the foot dorsiflexors. ${ }^{2}$ FSHD2 has digenic inheritance (4qA and SMCHD1) and is more likely to be sporadic $(67 \%) .^{2}$ This case was challenging diagnostically due to the isolated periscapular involvement, which was symmetrical with a minimally raised $\mathrm{CK}$, no myopathic changes on EMG and absent family history. The MRI was useful to confirm the pattern of muscle involvement in the shoulder girdle as typical for FSHD, in which trapezius, serratus anterior and teres major have been identified as the most commonly affected muscles, and additionally demonstrates the subclinical lower limb involvement. ${ }^{3}$ A small study found that the pattern of muscle involvement on MRI is the same in FSHD1 and FSHD2. ${ }^{4}$ The MRI findings supported further genetic testing rather than undertaking a muscle biopsy, which may otherwise have been considered.

Acknowledgements This research was supported by the National Institute for Health Research University College London Hospitals Biomedical Research Centre.

Contributors AJ (first author) and JMM (corresponding author) contributed to the conception of the paper, acquired the data that was used and approved the final version published. SS analysed and interpreted the images included in the paper. AJ drafted the article and all authors then revised it critically for important intellectual content. AJ, SS and JMM agreed to be accountable for the article 
Images in...

and will ensure that all questions regarding the accuracy or integrity of the article are investigated and resolved.

Funding The authors have not declared a specific grant for this research from any funding agency in the public, commercial or not-for-profit sectors.

Competing interests None declared.

Patient consent for publication Obtained.

Provenance and peer review Not commissioned; externally peer reviewed.

\section{REFERENCES}

1 Sacconi S, Briand-Suleau A, Gros M, et al. FSHD1 and FSHD2 form a disease continuum. Neurology 2019;92:e2273-85.

2 de Greef JC, Lemmers RJLF, Camaño P, et al. Clinical features of facioscapulohumeral muscular dystrophy 2. Neurology 2010;75:1548-54.

3 Gerevini S, Scarlato M, Maggi L, et al. Muscle MRI findings in facioscapulohumeral muscular dystrophy. Eur Radiol 2016;26:693-705.

4 Mair D, Huegens-Penzel M, Kress W, et al. Leg muscle involvement in facioscapulohumeral muscular dystrophy: comparison between facioscapulohumeral muscular dystrophy types 1 and 2. Eur Neurol 2017;77:32-9.

Copyright 2020 BMJ Publishing Group. All rights reserved. For permission to reuse any of this content visit

https://www.bmj.com/company/products-services/rights-and-licensing/permissions/

BMJ Case Report Fellows may re-use this article for personal use and teaching without any further permission.

Become a Fellow of BMJ Case Reports today and you can:

- Submit as many cases as you like

- Enjoy fast sympathetic peer review and rapid publication of accepted articles

- Access all the published articles

Re-use any of the published material for personal use and teaching without further permission

Customer Service

If you have any further queries about your subscription, please contact our customer services team on +44 (0) 2071111105 or via email at support@bmj.com.

Visit casereports.bmj.com for more articles like this and to become a Fellow 